02 Royal Netherlands Institute for Sea Research

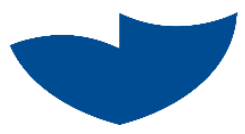

This is a postprint of:

Rampen, S.W., Willmott, V., Kim, J.-H., Rodrigo-Gámiz, M., Uliana, E., Mollenhauer, G., Schefuß, E., Sinninghe Damsté, J.S., \& Schouten, S. (2014). Evaluation of long chain 1,14-alkyl diols in marine sediments as indicators for upwelling and temperature. Organic Geochemistry, 76, 39-47

Published version: $\underline{\mathrm{dx} . \text { doi.org/10.1016/i.orggeochem.2014.07.012 }}$

Link NIOZ Repository: www.vliz.be/nl/imis?module=ref\&refid=243227

[Article begins on next page]

The NIOZ Repository gives free access to the digital collection of the work of the Royal Netherlands Institute for Sea Research. This archive is managed according to the principles of the Open Access Movement, and the Open Archive Initiative. Each publication should be cited to its original source - please use the reference as presented.

When using parts of, or whole publications in your own work, permission from the author(s) or copyright holder(s) is always needed. 


\section{Evaluation of long chain 1,14-alkyl diols in marine sediments as indicators for upwelling and temperature}

Sebastiaan W. Rampen ${ }^{a^{*}}$, Verónica Willmott ${ }^{a 1}$, Jung-Hyun Kim ${ }^{\text {a }}$, Marta Rodrigo-Gámiz a ,

5 Eleonora Uliana ${ }^{\text {b }}$, Gesine Mollenhauer ${ }^{\text {b,c }}$, Enno Schefuß ${ }^{\text {b }}$, Jaap S. Sinninghe Damsté ${ }^{a}$, Stefan Schouten ${ }^{\mathrm{a}}$

a NIOZ Royal Netherlands Institute for Sea Research, Department of Marine Organic Biogeochemistry, P.O. Box 59, 1790 AB Den Burg, Texel, The Netherlands

${ }^{\mathrm{b}}$ MARUM Center for Marine Environmental Sciences, University of Bremen, Leobener Strasse, D-28359, Bremen, Germany

${ }^{\mathrm{c}}$ Alfred-Wegener-Institute for Polar and Marine Research, Am Handelshafen 12, D-27570 Bremerhaven, Germany

1 Present address: Alfred-Wegener-Institute for Polar and Marine Research, Am Handelshafen 12, D-27570 Bremerhaven, Germany.

*Corresponding author. E mail address: sebastiaan.rampen@nioz.nl. 


\begin{abstract}
Long chain alkyl diols form a group of lipids occurring widely in marine environments. Recent studies have suggested several palaeoclimatological applications for proxies based on their distributions, but also revealed uncertainties about their applicability. Here we evaluate the use of long chain 1,14-alkyl diol indices for reconstruction of temperature and upwelling conditions by comparing index values, obtained from a comprehensive set of marine surface sediments, with environmental factors like sea surface temperature (SST), salinity and nutrient concentrations. Previous cultivation efforts indicated a strong effect of temperature on the degree of saturation and the chain length distribution of long chain 1,14-alkyl diols in Proboscia spp., quantified in the diol saturation index (DSI) and diol chain length index (DCI), respectively. However, values of these indices in surface sediments show no relationship with annual mean SST of the overlying water. It remains unknown what determines the DSI, although our data suggests that it may be affected by diagenesis, while the relationship between temperature and DCI may be different for different Proboscia species. In addition, contributions of algae other than Proboscia diatoms may affect both indices, although our data provide no direct evidence for additional long chain 1,14-alkyl diol sources. Two other indices using the abundance of 1,14-diols vs. 1,13-diols and $\mathrm{C}_{30}$ 1,15-diols have previously been applied as indicators for upwelling intensity at different locations. The geographical distribution of their values supports the use of 1,14 diols vs. 1,13 diols $\left[\mathrm{C}_{28}+\right.$ $\mathrm{C}_{30}$ 1,14-diols $] /\left[\left(\mathrm{C}_{28}+\mathrm{C}_{30} 1,13\right.\right.$-diols $)+\left(\mathrm{C}_{28}+\mathrm{C}_{30}\right.$ 1,14-diols $\left.)\right]$ as a general indicator for high nutrient or upwelling conditions.
\end{abstract}

Keywords: Long chain alkyl diols; Proboscia; Upwelling index; Sea surface Temperature index 


\section{Introduction}

Over the last decades, an increasing number of lipids from marine environments has been identified and linked to their natural sources, and some of them are now being used as proxies for past climate conditions (e.g. Eglinton and Eglinton, 2008 and references therein). Long chain alkyl diols form one group with high biomarker potential; after their discovery in the Black Sea (De Leeuw et al., 1981), they have been identified widespread in Quaternary sediments from low to high latitudes (Versteegh et al., 1997; 2000 and references therein). Cultured marine and freshwater eustigmatophyte algae produce series of long chain alkyl diols, consisting mainly of $\mathrm{C}_{28}-\mathrm{C}_{32}$ 1,13- and 1,15-diols (Volkman et al., 1999; 1992). In the environment, a recent study on lipids and 18s rRNA genes in a freshwater lake has shown that long chain alkyl diols are produced by eustigmatophytes in the surface waters of the lake (Villanueva et al., 2014). However, the role of eustigmatophytes as a source of marine long chain alkyl diols remains unclear. Reports of eustigmatophyte algae in marine environments are sparse and the long chain alkyl diol composition of marine eustigmatophytes does not match those of marine sediments (Volkman et al., 1992; Versteegh et al., 1997; Rampen et al., 2012). Despite uncertainties concerning their sources, recent work has indicated a strong correlation between sea surface temperatures (SST) and the fractional abundances of $\mathrm{C}_{28} 1$,13, $\mathrm{C}_{30}$ 1,13- and $\mathrm{C}_{30}$ 1,15-diols in marine sediments. Based on this, a new temperature proxy, i.e. the long chain diol index (LDI), which expresses the $\mathrm{C}_{30}$ 1,15-diol abundance relative to those of $\mathrm{C}_{28}$ 1,13-, $\mathrm{C}_{30}$ 1,13- and $\mathrm{C}_{30}$ 1,15-diols, was introduced (Rampen et al., 2012). A strong correlation (R-value of 0.984 and p-value of $<0.001$ ) between the LDI and SST was observed.

Besides 1,13- and 1,15-diols, long chain 1,14-alkyl diols are commonly reported in marine sediments. Sinninghe Damsté et al. (2003) and Rampen et al. (2007) showed that cultivated Proboscia diatoms produce both saturated and mono-unsaturated $\mathrm{C}_{28}$ and $\mathrm{C}_{30}$ 1,14-diols, and 
in addition, saturated $\mathrm{C}_{28}, \mathrm{C}_{30}$ and $\mathrm{C}_{32}$ 1,14-diols were recently reported in the marine Dictyochophyte Apedinella radians (Rampen et al., 2011). Sediment trap studies confirmed Proboscia diatoms being a likely source for long chain 1,14-alkyl diols, particularly in upwelling areas (Rampen et al., 2008), whereas the importance of Apedinella as a source for sedimentary long chain 1,14-alkyl diols remains uncertain (Rampen et al., 2011). These sources may be distinguished based on the occurrence of certain diols: $\mathrm{C}_{32}$ 1,14-diols may be useful as an indicator for Apedinella input, as they are produced by Apedinella radians and were absent from the 8 cultures of Proboscia spp. analyzed to date. Mono-unsaturated long chain 1,14-alkyl diols, on the other hand, may indicate Proboscia as a source, as these lipids have been identified in Proboscia cultures but not in Apedinella.

We previously reported that the chain length distribution and degree of saturation of long chain 1,14-alkyl diols in Proboscia cultures are related to growth temperature, indicating the potential of these diols to be used as a tool for reconstructing SST (Rampen et al., 2009). Changes in the chain length and degree of unsaturation of lipids are known adaptation mechanisms for bacteria, yeast, fungi and algae to changing environmental conditions (e.g. Russell and Fukunaga, 1990; Suutari and Laakso, 1994) and the following two indices, the Diol Chain length Index (DCI) and the Diol Saturation Index (DSI), were used to quantify the chain length distribution and degree of saturation of long chain diols:

$\mathrm{DCI}=\left[\right.$ saturated $\mathrm{C}_{30}$ 1,14-diol $] /\left[\right.$ saturated $\mathrm{C}_{28}+\mathrm{C}_{30}$ 1,14-diol $]$

However, application of these indices using surface sediments from the eastern South Atlantic Ocean showed only a moderate correlation of DCI with annual mean SST, while no correlation was observed between DSI and SST (R-values of 0.72 and 0.55 and p-values 
$<0.001$ and 0.535 , respectively; Rampen et al., 2009). It was suggested that factors other than temperature could also play a role, indicating that more data was required to validate the use of long chain 1,14-alkyl diols as a proxy for temperature.

Proboscia diatoms are often abundant in nutrient-rich environments like upwelling areas (Hernández-Becerril, 1995; Koning et al., 2001; Lange et al., 1998; Smith, 2001) and their lipids may, therefore, be useful as tracers for these conditions. Indeed, sediment trap studies showed that, in the Arabian Sea, long chain 1,14-alkyl diols were found almost exclusively under upwelling conditions (Rampen et al., 2008; 2007), whereas such a relationship was not observed for long chain 1,15- and 1,13-diols. Following this, Diol Index 1 was introduced:

Diol Index $1=$ [saturated $\mathrm{C}_{28}+\mathrm{C}_{30}$ 1,14-diol] / ([saturated $\mathrm{C}_{28}+\mathrm{C}_{30}$ 1,14-diol] + [saturated

$\mathrm{C}_{30}$ 1,15-diol])

Diol Index 1 has been used as a proxy for upwelling in the Arabian Sea (Rampen et al., 2008), the Benguela Upwelling System (Pancost et al., 2009), the Eastern Equatorial Pacific (Seki et al., 2012), offshore Southeastern Australia (Lopes dos Santos et al., 2012) and the westernmost Mediterranean (Nieto-Moreno et al., 2013).

Proboscia diatoms are also abundant in Antarctic waters and lipid analyses confirmed the presence of $\mathrm{C}_{28}$ and $\mathrm{C}_{30}$ 1,14-diols in a sediment core from the Western Bransfield Basin (Willmott et al., 2010). However, unlike the Arabian Sea, $\mathrm{C}_{30}$ 1,15-diol concentrations are low, whereas $\mathrm{C}_{28}$ and $\mathrm{C}_{30}$ 1,13-diols are more abundant in this area, and consequently Willmott et al. (2010) introduced the Diol Index 2 to reconstruct upwelling of nutrient rich Upper Circumpolar Deep Water in the Western Bransfield Basin:

Diol Index $2=$ [saturated $\mathrm{C}_{28}+\mathrm{C}_{30}$ 1,14-diol] $/\left(\left[\right.\right.$ saturated $\mathrm{C}_{28}+\mathrm{C}_{30}$ 1,14-diol] + [saturated $\mathrm{C}_{28}+\mathrm{C}_{30}$ 1,13-diol]) 
How widely applicable these long chain alkyl diol indices are as tracers for upwelling and nutrient rich conditions is unknown. In a study of Pliocene sediments from the Benguela Upwelling System, Pancost et al. (2009) observed both periods in which trends in 1,14-diol abundances and Diol Index 1 were consistent with those of other productivity markers, and periods where they differed. Contreras et al. (2010) related the increasing abundance of the $\mathrm{C}_{28}$ 1,14-diol in the Peruvian upwelling system during the last interglacial to enhanced stratification, the abundance being low during periods with presumed strengthened upwelling. In addition, several studies reported high Proboscia diatom abundance under stratified rather than upwelling conditions (e.g. Table 1). Hence, perhaps the Diol Indices should rather be used as indicators for Proboscia productivity, which can be linked to different environmental conditions depending on the region studied.

To constrain the applicability of long chain 1,14-alkyl diols as indicators for temperature, 130 upwelling/nutrient availability and other climate conditions, we have analyzed the long chain alkyl diol distributions in a comprehensive set of marine surface sediments $(n=209)$, previously studied for long chain 1,13- and 1,15-alkyl diols (Rampen et al., 2012), and compared various long chain 1,14-alkyl diol indices with environmental parameters of the overlaying surface waters, such as temperature, salinity, nutrient concentrations, stratification 135 and mixed layer depths.

\section{Methodology}

We analyzed 209 marine surface sediments, globally distributed, although mostly from the North and South Atlantic Oceans (Fig. 1 and Supplementary Material). Long chain alkyl diol fractions were obtained and analyzed as described by Rampen et al. (2012). Briefly, sediments were extracted using accelerated solvent extraction (ASE) using a DIONEX 200 instrument 
with a mixture of dichloromethane (DCM) and methanol $(\mathrm{MeOH})(9: 1 ; \mathrm{v}: \mathrm{v})$ at $100^{\circ} \mathrm{C}$ and $7-8$ $\times 10^{6} \mathrm{~Pa}$. For a selected set of samples, the ASE extracts were subsequently saponified with $6 \% \mathrm{KOH}$, according to De Leeuw et al. (1983), to release extractable ester-bound long-chain

145 alkyl diols. Extracts and saponified extracts were separated into apolar and polar fractions using a pipette column filled with activated alumina and elution with hexane/DCM (9:1; v:v) and DCM/ MeOH (1:1; v:v), respectively, or into apolar, keto and polar fractions using a pipette column filled with silica-gel (silica 60) with hexane, hexane/DCM (1:4; v:v) and DCM/MeOH (1:1; v:v), respectively. The polar fraction was analyzed, after silylation of

150 alcohols to the trimethyl silyl (TMS) derivatives, with gas chromatography-mass spectrometry (GC-MS). Fractional abundances of the long chain alkyl diols were calculated from relevant peak areas of mass chromatograms obtained using selected ion monitoring (SIM) of $\mathrm{m} / \mathrm{z} 299$, 313, 327, 341 and 355, which represent characteristic fragment ions of the relevant diols (Versteegh et al., 1997). Differences in the contribution of the selected ions to the total mass 155 spectra $(\mathrm{m} / \mathrm{z}, 50-800)$ of saturated and unsaturated long chain alkyl diols were taken into account as described by Rampen et al. (2009).

The long chain alkyl diol data were compared with temperature and salinity data from the $0.25^{\circ}$ grid 2001 World Ocean Database (WOA; Boyer et al., 2005), nitrate, phosphate and silicate concentrations from the $1^{\circ}$ grid 2009 WOA (Levitus, 2010), chlorophyll abundance 160 from the $1^{\circ}$ grid 2001 WOA (Levitus, 2002), and with mixed layer depth data (defined as the depth at which the temperature differs more than $0.5^{\circ} \mathrm{C}$ from the ocean surface temperature), obtained from the $1^{\circ}$ grid 1994 WOA (Monterey and Levitus, 1997).

\section{Results and discussion}


Surface sediments (generally $0-1 \mathrm{~cm}$ ) were obtained at locations with water depths ranging from ca. 20 to ca. $6000 \mathrm{~m}$ and a large range in annual mean SST $\left(-1.8-28.8^{\circ} \mathrm{C}\right)$, annual mean salinity $(6.8-37.0)$, nutrient concentrations, chlorophyll content $(0-280 \mu \mathrm{g} / \mathrm{L})$ and mixed layer depth $(0.1-65 \mathrm{~m})$ (see Supplementary Table 2). 187 sediments of this set $(89 \%)$ contained quantifiable (i.e. signal to noise ratio > 10) 1,13- and/or 1,15-alkyl diols, together with 1,14- alkyl diols, although unsaturated long chain 1,14-alkyl diols were only detected in 146 sediments (70\%). One sediment contained quantifiable amounts of long chain 1,13- and 1,15-alkyl diols without detectable amounts of long chain 1,14-alkyl diols. The observed chain lengths were $\mathrm{C}_{28}$ and $\mathrm{C}_{30}$ for 1,13- and 1,14-alkyl diols, and $\mathrm{C}_{30}$ and $\mathrm{C}_{32}$ for 1,15-alkyl diols. The $\mathrm{C}_{32}$ 1,14-alkyl diol, previously reported in Apedinella radians (Rampen et al., 2011), was not detected.

Long chain 1,14-alkyl diols dominate in the Arctic and Antarctic surface sediments and the Arabian Sea (Fig. 2), while their fractional abundances show strong variation in the other oceanic areas. For most regions, fractional abundances of 1,15-alkyl diols are inversely related to 1,14-alkyl diol abundances, while 1,13-alkyl diol abundances are generally low with little variation - only in estuarine sediments from Hudson Bay and the Gulf of St. Lawrence do 1,13 -alkyl diols contribute $>25 \%$ of the total long chain alkyl diols.

\subsection{Effect of environmental conditions on long chain 1,14-alkyl diol distributions}

The degree of saturation (as expressed in the DSI) and the chain length distribution (as expressed in the DCI) of long chain 1,14-alkyl diols in Proboscia diatom cultures have previously been reported to show a strong relationship with growth temperature, although the relationships were less apparent in a limited set of surface sediments from the eastern South Atlantic (Rampen et al., 2009). In order to examine the influence of various environmental 
factors on the DSI and DCI, we correlated their values with annual mean temperature, salinity, chlorophyll, phosphate, nitrate and silicate concentrations from the overlaying water at $0 \mathrm{~m}$ water depth, and with stratification (Table 2; Supplementary Table 3).

The DSI values show a weak negative correlation with SST $(\mathrm{R}$-value $=-0.441, \mathrm{p}$-value $<$ 0.001; Table 2; Fig. 3a), contrasting with the positive temperature correlation observed for cultured Proboscia diatoms by Rampen et al. (2009). We observed no regional pattern in the distribution of DSI values - strong differences in values were found for surface sediments taken within the same oceanic areas with similar annual mean SST (Fig. 3a). Moreover, analysis of data sets of different regions also did not reveal any strong correlations with annual or seasonal SST (Supplementary Table 3), confirming that temperature is not the only factor affecting DSI (Rampen et al., 2009). The lack of correlation between DSI and other environmental parameters included in this study (Table 2; Supplementary Table 3) suggest that they do not significantly impact the DSI. In Proboscia cultures, concentrations of unsaturated long chain alkyl diols were always similar or higher than saturated long chain alkyl diols; the often low abundance and sometimes absence of unsaturated 1,14-alkyl diols in marine surface sediments may indicate that unsaturated long chain alkyl diols are more strongly affected by diagenesis than saturated long chain alkyl diols. On the other hand, some of the surface sediments from the West African coast and the eastern South Atlantic contain relatively high amounts of unsaturated 1,14-alkyl diols, higher than would be expected based on culture results (Fig. 3a). Another factor affecting the DSI could be that we mostly analyzed freely occurring long chain alkyl diols (see Fig. 4, where open blue triangles indicate data for samples where extracts were not saponified, and open red circles indicate samples where extracts were saponified), whereas these lipids also occur in various bound forms, which may comprise different distributions (cf. Hoefs et al., 2002; Shimokawara et al., 2010; Volkman et al., 1992). To test this, we selected a subset of surface sediments for which diols were 
analyzed both without and with prior saponification of the extract. Fig. 4 shows the various long chain alkyl diol indices plotted versus annual SST. Filled symbols indicate the data for saponified (red circles) and non-saponified (blue triangles) surface sediments of the selected dataset. For most sediments tested, the DSI shows markedly lower values after saponification (Fig. 4a), indicating that the fraction of mono-unsaturated long chain alkyl diols released by saponification is higher compared to this fraction in free lipids. Nevertheless, neither the DSIvalues of saponified nor free long chain alkyl diols show a strong correlation with temperature (Fig. 4a), suggesting the DSI is also affected by factors other than temperature.

We also observe no statistically significant correlation between SST and the chain length of the 1,14-alkyl diols (Fig. 3b), while weak to moderate correlations are observed between DCI and silicate, nitrate and, most strongly, phosphate concentrations (Table 2).

225 Saponification of the extracts resulted in slightly lower DCI values (Fig. 4b) and, apparently, the release of bound long chain 1,14-alkyl diols did not substantially improve the correlation between DCI and SST. The lack of correlation between the DCI and SST is in contrast with previous results for surface sediments from the eastern South Atlantic (Rampen et al., 2009) and a more detailed analysis shows that the DCI values from specific areas follow distinct patterns (Fig. 3b). Firstly, Arctic sediments from the Barents Sea and around Svalbard all show high DCI values around 0.8-0.9, whereas Antarctic sediments show values around 0.1 without a temperature trend. Secondly, as shown before, DCI values from eastern South Atlantic sediments are higher than expected on the basis of culture experiments (Rampen et al., 2009), while surface sediments along the West African coast with a similar SST show substantially lower DCI values. Thirdly, only for surface sediments from the Central and Western South Atlantic Ocean do DCI values correlate with SST, with the western South Atlantic data resembling the temperature correlation observed for Proboscia cultures. Previous studies have shown that Proboscia species proliferate in different seasons (e.g. Table 
1) and therefore their long chain 1,14-alkyl diol distributions may reflect different seasonal temperatures, which may be an explanation for some of the scatter in the DCI-SST relationship. However, even correlations between regional DCI values and monthly SSTs remained weak (Supplementary Table 3). In addition, seasonal growth cannot explain why, for example, highest DCI-values were observed for Arctic sediments (Fig. 3b). As implied by the moderate correlation between DCI and nutrient concentrations (Table 2), the DCI may 245 also be affected by environmental factors other than temperature or by the physiological state of the long chain 1,14-alkyl diol producers. The different DCI/SST patterns for the various locations could also be an indication that different species of Proboscia have their own specific relationship with temperature. The correlation between DCI and growth temperature is mainly based on cultures of $P$. indica (Rampen et al., 2009). Proboscia alata is a cosmopolitan species (Table 1) but other Proboscia spp. are restricted to specific areas, which may be related to specific environmental factors like nutrient availability, salinity or temperature (e.g. Jordan et al., 1991; Takahashi et al., 1994). A regional occurrence, related to environmental factors, of Proboscia species with specific long chain diol distributions may also explain the weak correlation observed between DCI and silicate, nitrate and phosphate 255 concentrations. Alternatively, the indices may be affected by input of diols from species other than Proboscia. Analyses of an extensive set of diatom cultures indicated that, except for Proboscia species, diatoms are an unlikely source for long chain alkyl diols (Rampen et al., 2007). However, recently, Rampen et al. (2011) did report long chain 1,14-alkyl diols in the heterokont marine Dictyochophyte Apedinella radians indicating that these lipids may indeed also be produced by algae other than diatoms. Moreover, the DCI value of the A. radians culture does not match with the results from Proboscia cultures (Fig. 3b). On the other hand, strong similarities between Proboscia frustule flux and long chain 1,14-alkyl diol flux in the Arabian Sea (Rampen et al., 2008) suggest that, at least in the Arabian Sea, Proboscia are the 
main source of long chain 1,14-alkyl diols. Furthermore, A. radians also contained $\mathrm{C}_{32}$ 1,14diol (Rampen et al., 2011), which was not detected in this study. Possibly in areas like the central and western South Atlantic the source of long chain 1,14-alkyl diols is predominantly a single Proboscia species and this may explain the apparent relationship between DCI and SST in these areas. Hence, the DCI may only be applicable as a temperature proxy if the biological source does not change over time, and its temperature-proxy relationship is known.

\subsection{Effect of environmental conditions on relative abundances of long chain 1,14-alkyl diols.}

Previously we introduced two diol indices, Diol Index 1 and 2 (Eq. 3 and 4), to reconstruct past upwelling conditions in the Arabian Sea and the shelf waters of the Western Antarctic Peninsula, respectively (Rampen et al., 2008; Willmott et al., 2010). To test the applicability

275 of these two long chain alkyl diol indices as upwelling or stratification proxies on a global scale, we determined their values in our marine surface sediment set. This sediment set contains samples from major coastal upwelling regimes like the Canary Current system (off Northwest Africa), the Benguela Current system (off Southern Africa), the Somali Current system (off Somalia and Oman) and the Southern Ocean around Antarctica (Capone and Hutchins, 2013; Orsi et al., 1995; Smith et al., 2001).

For Diol Index 1, highest values (>0.9) were observed in both northern and southern highlatitude areas $\left(>60^{\circ}\right)$, while typical upwelling areas in the Arabian Sea, off the coast of West Africa and in the eastern South Atlantic Ocean showed moderate to low index values (Fig. 5a), suggesting that Diol Index 1 is not an unambiguous indicator for upwelling conditions.

285 The values of Diol Index 2 showed a geographical distribution distinctly different from Diol Index 1 (Fig. 5). Highest Diol Index 2 values are observed near Antarctica, the Arabian Sea and West Africa, and moderate to high values in the eastern South Atlantic Ocean. Northern 
high latitude areas $\left(>60^{\circ} \mathrm{N}\right)$ show Diol Index 2 values, which are slightly lower than southern high latitudes. Based on its reasonable correspondence of high values with upwelling conditions, Diol Index 2 seems to be a better general indicator for upwelling conditions than Diol Index 1. We also examined a combination of both indices,

Combined Diol Index $=\left[\mathrm{C}_{28}+\mathrm{C}_{30} 1,14-\right.$ diol $] /\left(\left[\mathrm{C}_{28}+\mathrm{C}_{30}\right.\right.$ 1,14-diol $]+\left[\mathrm{C}_{28}+\mathrm{C}_{30}\right.$ 1,13-diol $]+$ $\left[\mathrm{C}_{30}\right.$ 1,15-diol])

295 but the results of the Combined Diol Index strongly resembled those of Diol Index 1, indicating no additional value (data not shown). We also investigated the effect of bound long chain alkyl diols on these indices, but the Diol Index values before and after saponification of the extracts have similar values (Figs. 4c and d).

Quantitative correlation of the long chain alkyl diol indices with upwelling strength are hampered by the relatively small quantitative data on upwelling strength, which is why upwelling is often inferred by indirect methods like measurements of wind stress, tracer observations, salinity, nutrients and temperature (Kadko and Johns, 2011; Rhein et al., 2010). Furthermore, most upwelling studies areas are on a regional scale, whereas data on upwelling on a global scale is limited to indications of presence or absence of upwelling in specific areas (e.g. Capone et al., 2013). In order to provide some quantitative comparison with upwelling strength, and to investigate whether certain environmental factors affect the two Diol Indices, we correlated the indices with temperature, salinity and chlorophyll, phosphate, nitrate and silicate concentrations of the overlaying water (Table 2). Diol Index 2 showed no correlation with these environmental factors, while Diol Index 1 showed a significant inverse correlation with SST $($ R-value $=-0.855$; p-value $<0.001$, Fig. 6). The correlation between SST and the Diol Index 1 is remarkable since the index is composed of lipids supposed to be produced by 
different organisms, so shifts in their relative abundance are unlikely to be related to physiological adaptation within single organisms. $\mathrm{C}_{30}$ 1,15-diol abundance shows an increase relative to 1,14-diol abundances with increasing temperature, similar to the LDI, whereas the

$\mathrm{C}_{30}$ 1,15-diol also increase relative to $\mathrm{C}_{28}$ 1,13- and $\mathrm{C}_{30}$ 1,13-diols with increasing temperature (Rampen et al., 2012). However, the LDI correlates much stronger with SST (R-value = 0.984) and similar LDI-temperature correlations are observed in different regions indicating that this index is primarily affected by temperature. In contrast, for Diol Index 1, upwelling areas at low latitudes like the Arabian Sea and West Africa show distinctly higher Diol Index

3201 values, whereas estuarine areas like the Hudson Bay and the Gulf of St. Lawrence show lower values for both Diol Index 1 and 2 compared to the global trends. This suggests that these diol indices are also affected by other factors than temperature (Fig. 6). In addition to temperature, nitrate, phosphate and silicate concentrations also showed significant correlations with the Diol Index 1, but these are likely due to the underlying correlation of these nutrients with SST (Rampen et al., 2012).

To investigate whether the degree of stratification is related with the Diol Indices (cf. Conteras et al., 2010), we compared the indices with the temperature differential between sea surface and subsurface at $200 \mathrm{~m}$ depth $\left(\mathrm{T}_{0}-\mathrm{T}_{200}\right.$, suggested as a measure for stratification by Dave and Lozier, 2013) and mean annual depths of the surface mixed layers. A significant correlation is only observed between Diol Index 1 and $\mathrm{T}_{0}-\mathrm{T}_{200}$, but again this may also be due to the strong correlation between SST and $T_{0}-T_{200}$. To examine the possibility of seasonal production of long chain 1,14-diols during months with maximum stratification, Diol Indices were also compared with stratification and mixed layer depth values for months with the shallowest mixing depths and smallest temperature differences, but also this revealed no relationships (see Supplementary Table 3). 
These results indicate that Diol Index 1 is unsuitable as a globally applicable upwelling indicator, although it does seem to work in certain regions (e.g. Rampen et al., 2008), while Diol Index 2 seems applicable as a global indicator for upwelling, although this will likely also depend on the local ecological niche of Proboscia diatoms.

\section{Conclusions}

Although it was previously reported that the chain length distribution and degree of saturation of long chain 1,14-alkyl diols in Proboscia cultures are related to growth temperature (Rampen et al., 2009), our comprehensive study of marine core tops does not show a strong correlation between SST and chain length distribution or degree of saturation of long chain 1,14-alkyl diols in marine surface sediments, indicating that these compounds are not widely applicable as a temperature proxy. It remains uncertain why these correlations are not observed in this core top study, but regional differences in source organisms may play an important role. Analyses of long chain alkyl diol indices proposed as indicators for upwelling/high nutrient factors indicate that Diol Index 1 is affected by temperature. The geographical distributions of Diol Index 2 values suggest that this index may be more widely applicable as an indicator for upwelling conditions although this will depend on the local ecological niche of Proboscia diatoms and their relationship with upwelling conditions. 


\section{Acknowledgements}

We thank J.K. Volkman and four anonymous reviewers for their constructive comments. N. Koç and D. Klitgaard Kristensen, the participants and the crew of the SciencePub IPYcruise in 2007 on the R/V Lance from the Norwegian Polar Institute are appreciated for their help for the Svalbard surface sediment sampling. Barents Sea samples collected within the Norwegian governmental mapping program MAREANO (www.mareano.no) were provided by J. Knies at Geological Survey of Norway. We are also grateful to various people who provided core-top sediments: A. Jaeschke, E. Epping and T. van Weering (NIOZ), the WHOI core repository, X. Crosta (EPOC), E. Michele and M.-A. Sicre (LSCE), N. Ohkouchi (JAMSTEC), B. Donner (RCOM), R. Smittenberg (ETH), A. Schimmelman (Indiana University), S. Wakeham (SKIO), T. Eglinton (ETH), E. Domack (Hamilton College), S. Jacobs (LDEO), A. deVernal (UQAM), C. Slomp, S. N. Fhlaithearta and F. Sangiorgi (Utrecht University). The research received funding from the European Research Council under the EU's Seventh Framework Programme (FP7/2007-2013) / ERC grant agreement $n^{\circ}$ 370 [226600], from a VICI grant to S.S. from the Earth and Life Sciences Division of the Netherlands Organization for Scientific Research (NWO-ALW), and the Spinoza prize to J.S.S.D. Supplementary Tables 1, 2 and 3 are available online at http://doi.pangaea.de/10.1594/PANGAEA.833787. 
Annett, A.L., Carson, D.S., Crosta, X., Clarke, A., Ganeshram, R.S., 2010. Seasonal progression of diatom assemblages in surface waters of Ryder Bay, Antarctica. Polar Biology 33, 13-29.

Boyer, T., Levitus, S., Garcia, H., Locarnini, R.A., Stephens, C., Antonov, J., 2005. Objective analyses of annual, seasonal, and monthly temperature and salinity for the world ocean on a $0.25^{\circ}$ grid. International Journal of Climatology 25, 931-945.

Brichta, M., Nöthig, E.-M., 2003. Proboscia inermis: A key diatom species in Antarctic autumn. AGU Chapman Conference: The role of Diatom Production and Si flux and Burial in the Regulation of Global Cycles, Paros, Greece.

Capone, D.G., Hutchins, D.A., 2013. Microbial biogeochemistry of coastal upwelling regimes in a changing ocean. Nature Geoscience 6,711-717.

Contreras, S., Lange, C.B., Pantoja, S., Lavik, G., Rincón-Martínez, D., Kuypers, M.M.M., 2010. A rainy northern Atacama Desert during the last interglacial. Geophysical Research Letters 37, L23612.

390 Dave, C.A., Lozier, S., 2013. Examining the global record of interannual variability in stratification and marine productivity in the low-latitude and mid-latitude ocean. Journal of geophysical research: Oceans 118, 3114-3127.

De Leeuw, J.W., Rijpstra, W.I.C., Schenck, P.A., 1981. The occurrence and identification of $\mathrm{C}_{30}, \mathrm{C}_{31}$ and $\mathrm{C}_{32}$ alkan-1,15-diols and alkan-15-one-1-ols in Unit I and Unit II Black Sea sediments. Geochimica et Cosmochimica Acta 45, 2281-2285.

De Leeuw, J.W., Rijpstra, W.I.C., Schenck, P.A., Volkman, J.K., 1983. Free, esterified and residual sterols in Black Sea Unit I sediments. Geochimica et Cosmochimica Acta 47, 455465.

Eglinton, T.I., Eglinton, G., 2008. Molecular proxies for paleoclimatology. Earth and Planetary Science Letters 275, 1-16.

Eker-Develi, E., Kideys, A.E., 2003. Distribution of phytoplankton in the southern Black Sea in summer 1996, spring and autumn 1998. Journal of Marine Systems 39, 203-211.

Estrada, M., Delgado, M., 1990. Summer phytoplankton distributions in the Weddell Sea. Polar Biology 10, 441-449.

405 Fernández, E., Bode, A., 1994. Succession of phytoplankton assemblages in relation to the hydrography in the southern Bay of Biscay: A multivariate approach. Scientia Marina 58, 191-205.

Gómez, F., Souissi, S., 2007. Unusual diatoms linked to climatic events in the northeastern English Channel. Journal of Sea Research 58, 283-290.

410 Hernández-Becerril, D.U., 1995. Planktonic diatoms from the Gulf of California and coasts off Baja California: The genera Rhizosolenia, Proboscia, Pseudosolenia, and former Rhizosolenia species. Diatom Research 10, 251-267.

Hoefs, M.J.L., Rijpstra, W.I.C., Sinninghe Damsté, J.S., 2002. The influence of oxic degradation on the sedimentary biomarker record I: Evidence from Madeira Abyssal Plain turbidites. Geochimica et Cosmochimica Acta 66, 2719-2735.

Jordan, R.W., Ligowski, R., Nöthig, E.-M., Priddle, J., 1991. The diatom genus Proboscia in Antarctic waters. Diatom Research 6, 63-78.

Kadko, D., Johns, W., 2011. Inferring upwelling rates in the equatorial Atlantic using ${ }^{7} \mathrm{Be}$ measurements in the upper ocean. Deep-Sea Research 1, 647-657.

420 Koning, E., Van Iperen, J.M., Van Raaphorst, W., Helder, W., Brummer, G.-J.A., Van Weering, T.C.E., 2001. Selective preservation of upwelling-indicating diatoms in sediments off Somalia, NW Indian Ocean. Deep-Sea Research I 48, 2473-2495. 
Lange, C.B., Hasle, G.R., Syvertsen, E.E., 1992. Seasonal cycle of diatoms in the Skagerrak, North-Atlantic, with emphasis on the period 1980-1990. Sarsia 77, 173-187.

425 Lange, C.B., Romero, O.E., Wefer, G., Gabric, A.J., 1998. Offshore influence of coastal upwelling off Mauritania, NW Africa, as recorded by diatoms in sediment traps at $2195 \mathrm{~m}$ water depth. Deep-Sea Research I 45, 986-1013.

Levitus, S., 2002. NOAA atlas. US Government Printing Office, Washington.

Levitus, S., 2010. NOAA atlas. Government Printing Office, Washington.

430 Lopes dos Santos, R.A., Wilkins, D., de Deckker, P., Schouten, S., 2012. Late Quaternary productivity changes from offshore Southeastern Australia: A biomarker approach. Palaeogeography, Palaeoclimatology, Palaeoecology 363-364, 48-56.

Moita, M.T., Oliveira, P.B., Mendes, J.C., Palma, A.S., 2003. Distribution of chlorophyll $a$ and Gymnodinium catenatum associated with coastal upwelling plumes off central Portugal. Acta Oecologica-International Journal of Ecology 24, S125-S132.

Monterey, G., Levitus, S., 1997. Seasonal variability of mixed layer depth for the world ocean, NOAA Atlas NESDIS 14. U.S. Gov. Printing Office, Washington.

Nehring, S., 1998. Establishment of thermophilic phytoplankton species in the North Sea: biological indicators of climatic changes? Ices Journal of Marine Science 55, 818-823.

440 Nieto-Moreno, V., Martínez-Ruiz, F., Willmott, V., García-Orellana, J., Masqué, P., Sinninghe Damsté, J.S., 2013. Climate conditions in the westernmost Mediterranean over the last two millennia: an integrated biomarker approach. Organic Geochemistry 55, 1-10.

O'Boyle, S., Silke, J., 2010. A review of phytoplankton ecology in estuarine and coastal waters around Ireland. Journal of Plankton Research 32, 99-118.

445 Orsi, A.H., Withworth, T., Nowlin, W.D., 1995. On the miridional extend and fronts of the Antarctic Circumpolar Current. Deep-Sea Research I. 42, 641-673.

Pancost, R.D., Boot, C.S., Aloisi, G., Maslin, M., Bickers, C., Ettwein, V., Bale, N., Handley, L., 2009. Organic geochemical changes in Pliocene sediments of ODP Site 1083 (Benguela Upwelling System). Paleogeography, Palaeoclimatology, Palaeoecology 280, 119-131.

450 Pike, J., Allen, C.S., Leventer, A., Stickley, C.E., Pudsey, C.J., 2008. Comparison of contemporary and fossil diatom assemblages from the western Antarctic Peninsula shelf. Marine Micropaleontology 67, 274-287.

Prahl, F.G., Wolfe, G.V., Sparrow, M.A., 2003. Physiological impacts on alkenone paleothermometry. Paleoceanography 18.

455 Quinlan, E.L., Phlips, E.J., 2007. Phytoplankton assemblages across the marine to low-salinity transition zone in a blackwater dominated estuary. Journal of Plankton Research 29, 401416.

Rampen, S.W., Schouten, S., Koning, E., Brummer, G.-J.A., Sinninghe Damsté, J.S., 2008. A $90 \mathrm{kyr}$ upwelling record from the northwestern Indian Ocean using a novel long-chain diol index. Earth and Planetary Science Letters 276, 207-213.

Rampen, S.W., Schouten, S., Schefuß, E., Sinninghe Damsté, J.S., 2009. Impact of temperature on long chain diol and mid-chain hydroxy methyl alkanoate composition in Proboscia diatoms: Results from culture and field studies. Organic Geochemistry 40, 1124-1131.

465 Rampen, S.W., Schouten, S., Sinninghe Damsté, J.S., 2011. Occurrence of long chain 1,14 diols in Apedinella radians. Organic Geochemistry 42, 572-574.

Rampen, S.W., Schouten, S., Wakeham, S.G., Sinninghe Damsté, J.S., 2007. Seasonal and spatial variation in the sources and fluxes of long chain diols and mid-chain hydroxy methyl alkanoates in the Arabian Sea. Organic Geochemistry 38, 165-179.

470 Rampen, S.W., Willmott, V., Kim, J.-H., Uliana, E., Mollenhauer, G., Schefuß, E., Sinninghe Damsté, J.S., Schouten, S., 2012. Long chain 1,13- and 1,15-diols as a potential proxy for palaeotemperature reconstruction. Geochimica et Cosmochimica Acta 84, 204-216. 
Rhein, M., Dengler, M., Sültenfuß, J., Hummels, R., Hüttl-Kabus, S., Bourles, B., 2010. Upwelling and associated heat flux in the equatorial Atlantic inferred from helium isotope disequilibrium. Journal of Geophysical Research 115, C08021.

Russell, N.J., Fukunaga, N., 1990. A comparison of thermal adaptation of membrane-lipids in psychrophilic and thermophilic bacteria. FEMS Microbiology Reviews 75, 171-182.

Seki, O., Schmidt, D.N., Schouten, S., Hopmans, E.C., Sinninghe Damsté, J.S., Pancost, R.D., 2012. Paleoceanographic changes in the Eastern Equatorial Pacific over the last $10 \mathrm{Myr}$.

$480 \quad$ Paleoceanography 27, PA3224.

Shimokwara, M., Nishimura, M., Matsuda, T., Akiyama, N., Takayoshi, K., 2010. Bound forms, compositional features, major sources and diagenesis of long chain, alkyl mid-chain diols in Lake Baikal sediments over the past 28,000 years. Organic Geochemistry 41, 753 766.

485 Silkin, V.A., Pautova, L.A., Lifanchuk, A.V., 2013. Physiological regulatory mechanisms of the marine phytoplankton community structure. Russian Journal of Plant Physiology 60, 541-548.

Sinninghe Damsté, J.S., Rampen, S., Rijpstra, W.I.C., Abbas, B., Muyzer, G., Schouten, S., 2003. A diatomaceous origin for long-chain diols and mid-chain hydroxy methyl alkanoates widely occurring in Quaternary marine sediments: Indicators for high nutrient conditions. Geochimica et Cosmochimica Acta 67, 1339-1348.

Smith, S.L., 2001. Understanding the Arabian Sea: Reflections on the 1994-1996 Arabian Sea Expedition. Deep-Sea Research II 48, 1385-1402.

Sukhanova, I.N., Flint, M.V., Whitledge, T.E., Stockwell, D.A., Rho, T.K., 2006. Mass development of the planktonic diatom Proboscia alata over the Bering Sea shelf in the summer season. Oceanology 46, 200-216.

Suutari, M., Laakso, S., 1994. Microbial fatty acids and thermal adaptation. Critical Reviews in Microbiology 20, 285-328.

Takahashi, K., 1987. Response of Subarctic Pacific diatom fluxes to the 1982-1983 El Niño disturbance. Journal of Geophysical Research-Oceans 92, 14387-14392.

Takahashi, K., Jordan, R., Priddle, J., 1994. The diatom genus Proboscia in subarctic waters. Diatom Research 9, 411-428.

Versteegh, G.J.M., Bosch, H.J., De Leeuw, J.W., 1997. Potential palaeoenvironmental information of $\mathrm{C}_{24}$ to $\mathrm{C}_{36}$ mid-chain diols, keto-ols and mid-chain hydroxy fatty acids; a critical review. Organic Geochemistry 27, 1-13.

Versteegh, G.J.M., Jansen, J.H.F., De Leeuw, J.W., Schneider, R.R., 2000. Mid-chain diols and keto-ols in SE Atlantic sediments: a new tool for tracing past sea surface water masses? Geochimica et Cosmochimica Acta 64, 1879-1892.

Villanueva, L., Besseling, M., Rodrigo-Gámiz, M., Rampen, S.W., Verschuren, D., Sinninghe Damsté, J.S., 2014. Potential biological sources of long chain alkyl diols in a lacustrine system. Organic Geochemistry 68,27-30.

Volkman, J.K., Barrett, S.M., Blackburn, S.I., 1999. Eustigmatophyte microalgae are potential sources of $\mathrm{C}_{29}$ sterols, $\mathrm{C}_{22}-\mathrm{C}_{28} n$-alcohols and $\mathrm{C}_{28}-\mathrm{C}_{32} n$-alkyl diols in freshwater environments. Organic Geochemistry 30, 307-318.

515 Volkman, J.K., Barrett, S.M., Dunstan, G.A., Jeffrey, S.W., 1992. C $30-C_{32}$ alkyl diols and unsaturated alcohols in microalgae of the class Eustigmatophyceae. Organic Geochemistry $18,131-138$.

Wasmund, N., Gobel, J., Von Bodungen, B., 2008. 100-years-changes in the phytoplankton community of Kiel Bight (Baltic Sea). Journal of Marine Systems 73, 300-322.

520 Willmott, V., Rampen, S.W., Domack, E., Canals, M., Sinninghe Damsté, J.S., Schouten, S., 2010. Holocene changes in Proboscia diatom productivity in shelf waters of the northwestern Antarctic Peninsula. Antarctic Science 22, 3-10. 
Table 1: Reports of dominant Proboscia occurrence, including location, season and typical conditions.

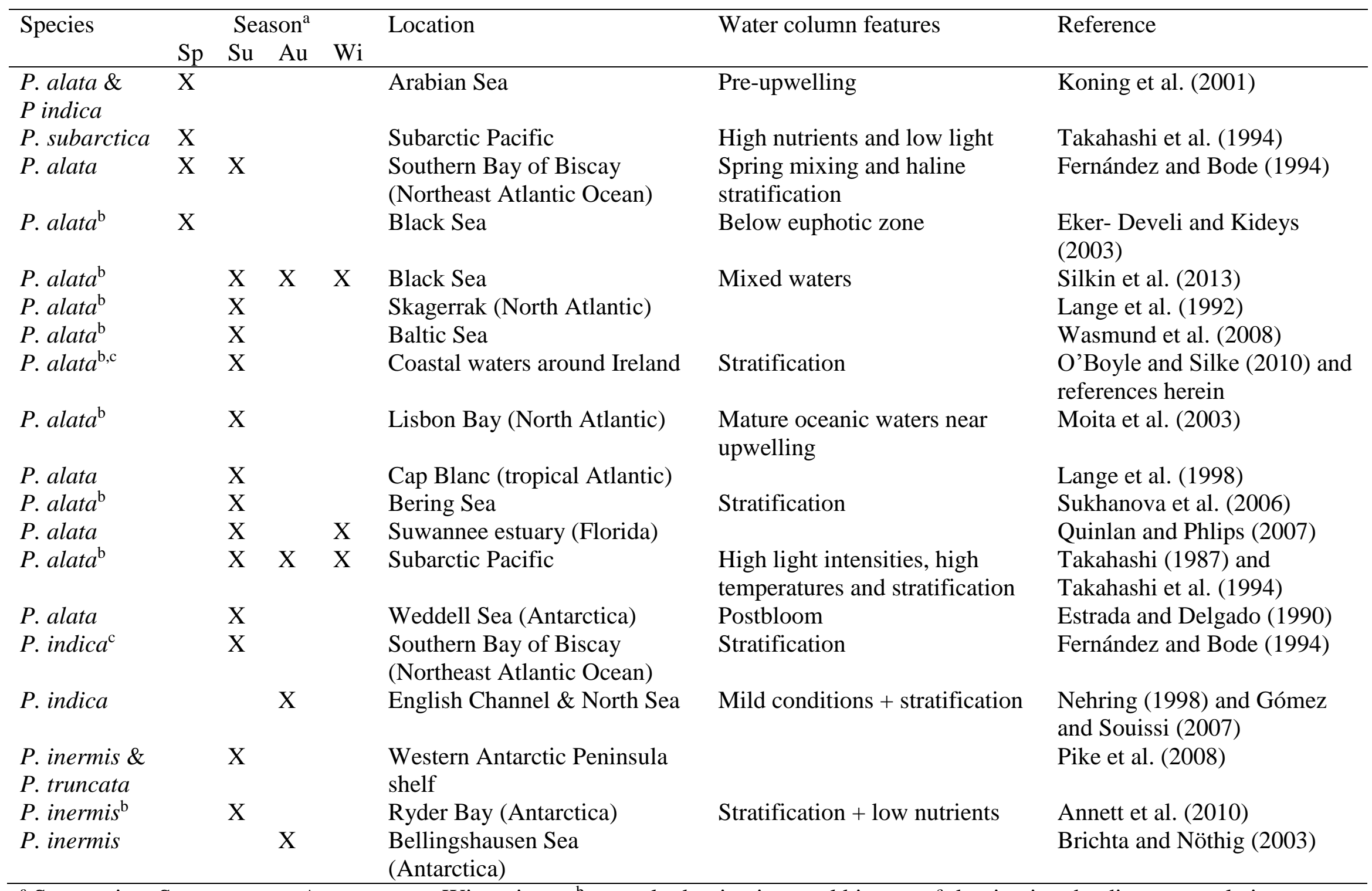

${ }^{\mathrm{a}} \mathrm{Sp}=$ spring, $\mathrm{Su}=$ summer, $\mathrm{Au}=$ autumn, $\mathrm{Wi}=$ winter; ${ }^{\mathrm{b}}$ strongly dominating total biomass; ${ }^{\mathrm{c}}$ dominating the diatom population. 
Table 2: Correlation between CDI, DSI, Diol Index 1, Diol Index 2 and annual mean values for environmental conditions for whole sample set $(\mathrm{n}-185$. Correlation coefficients $>0.5$ or $<-0.5$ are indicated in bold; R, correlation coefficient; P, p-value). See supplementary data for correlations on a regional scale.

\begin{tabular}{|c|c|c|c|c|c|c|c|c|c|}
\hline & & $\mathrm{SST}^{\mathrm{a}}$ & Salinity $^{\mathrm{a}}$ & Chlorophyll & Nitrate $^{\mathrm{c}}$ & Phosphate $^{\mathrm{c}}$ & Silica $^{c}$ & $\operatorname{MLD}^{\mathrm{d}}$ & $\mathrm{T}_{0}-\mathrm{T}_{200^{\mathrm{a}}}$ \\
\hline \multirow[t]{2}{*}{ DSI } & $\mathrm{R}$ & -0.441 & -0.160 & -0.028 & 0.237 & 0.263 & 0.258 & 0.220 & -0.398 \\
\hline & $\mathrm{P}$ & $<0.001$ & 0.030 & 0.702 & 0.001 & $<0.001$ & $<0.001$ & 0.003 & $<0.001$ \\
\hline \multirow[t]{2}{*}{ DCI } & $\mathrm{R}$ & 0.049 & 0.132 & -0.150 & -0.589 & -0.660 & -0.570 & 0.133 & 0.045 \\
\hline & $\mathrm{P}$ & 0.510 & 0.073 & 0.042 & $<0.001$ & $<0.001$ & $<0.001$ & 0.072 & 0.542 \\
\hline \multirow[t]{2}{*}{ Diol Index 1} & $\mathrm{R}$ & -0.855 & -0.126 & 0.017 & 0.579 & 0.549 & 0.479 & 0.303 & -0.840 \\
\hline & $\mathrm{P}$ & $<0.001$ & 0.088 & 0.819 & $<0.001$ & $<0.001$ & $<0.001$ & $<0.001$ & $<0.001$ \\
\hline \multirow[t]{2}{*}{ Diol Index 2} & $\mathrm{R}$ & 0.068 & 0.447 & -0.077 & 0.185 & 0.131 & 0.275 & 0.001 & -0.001 \\
\hline & $\mathrm{P}$ & 0.359 & $<0.001$ & 0.297 & 0.012 & 0.075 & $<0.001$ & 0.988 & 0.993 \\
\hline
\end{tabular}

\footnotetext{
${ }^{a}$ Boyer et al. (2005); ${ }^{b}$ Levitus (2002); ${ }^{c}$ Levitus (2010); ${ }^{d}$ mixed layer depth (Monterey and Levitus, 1997).
} 


\section{Figure legends:}

Fig. 1. Sample location and presence of quantifiable amounts (signal to noise > 10) of different long chain alkyl diols.

535 Fig. 2. Ternary diagram showing relative abundance of $\mathrm{C}_{28}$ and $\mathrm{C}_{30}$ 1,13-alkyl diols, $\mathrm{C}_{28}$ and $\mathrm{C}_{30}$ 1,14-alkyl diols and $\mathrm{C}_{30}$ and $\mathrm{C}_{32}$ 1,15-alkyl diols in surface sediments. Colours indicate different sampling areas.

Fig. 3. Cross plot of (a) degree of saturation in long chain 1, 14-alkyl diols (DSI) and (b) 1,14alkyl diol chain length index (DCI) vs. annual mean SST. Colours indicate different areas (see

540 fig. 2 for map) while black squares DCI values from cultured algae (data from Rampen et al., 2009; 2011).

Fig. 4. Cross plots of long chain diol indices vs. annual mean SST. Open blue triangles indicate data from free lipids in ASE extracts while open pink circles indicate data from samples which were analyzed after saponification of the ASE extracts. Filled symbols indicate the data from a 545 selected set of samples which were analyzed both before and after saponification; The filled blue triangles indicate free lipids in ASE extracts while the filled red circles indicate data obtained after saponification of the ASE extracts. (a) degree of saturation in long chain 1, 14-alkyl diols (DSI), (b) 1,14-alkyl diol chain length index (DCI), (c) Diol Index 1 and (d) Diol Index 2 values vs. annual mean SST.

550 Fig. 5. World map with the values of (a) Diol Index 1 and (b) Diol Index 2 at the sample locations. 
Fig. 6. Cross plot of (a) Diol Index 1 and (b) Diol Index 2 vs. annual mean SST. Colours indicate different areas (see Fig. 2 for map). 
Fig. 1.

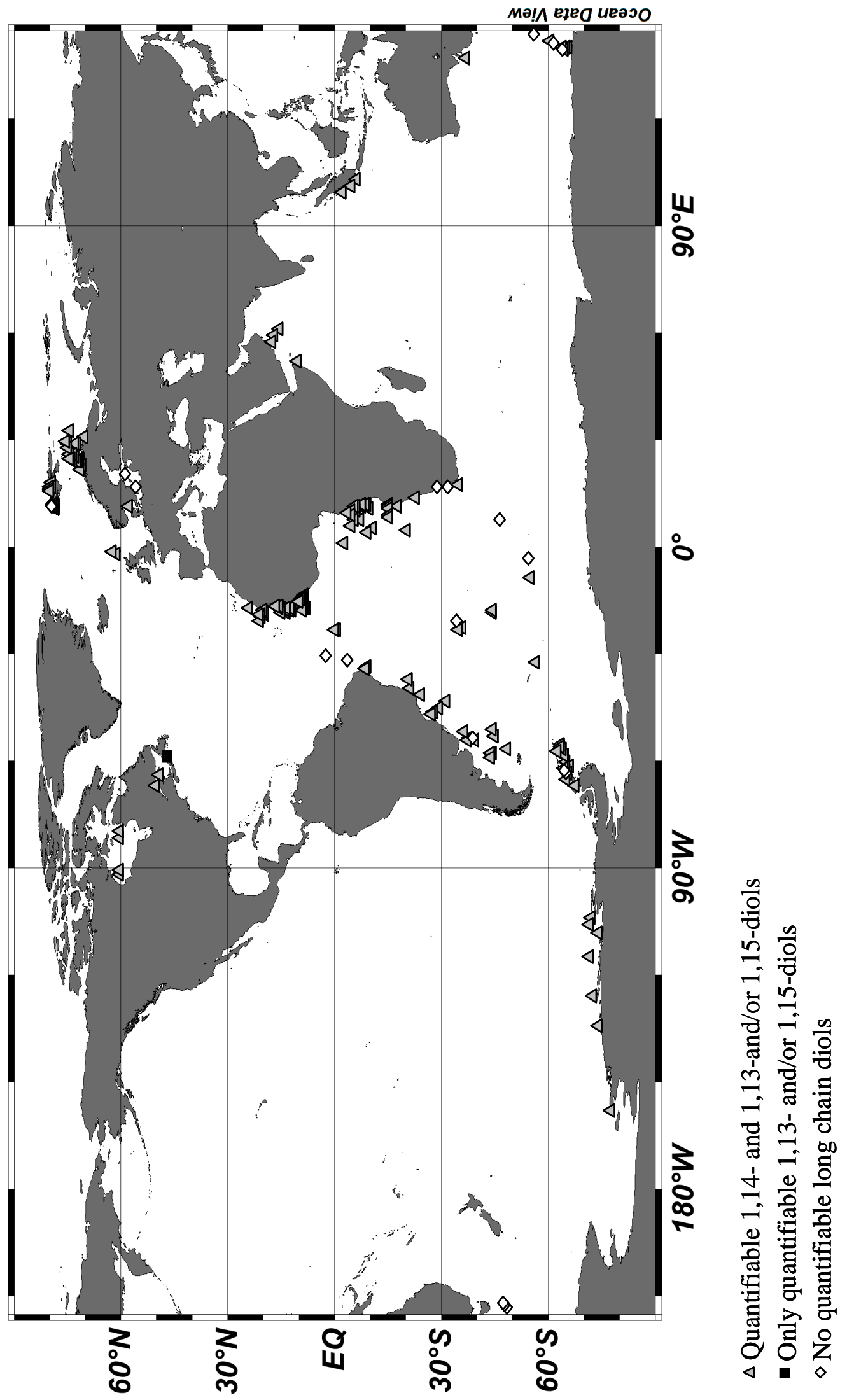


Fig. 2.

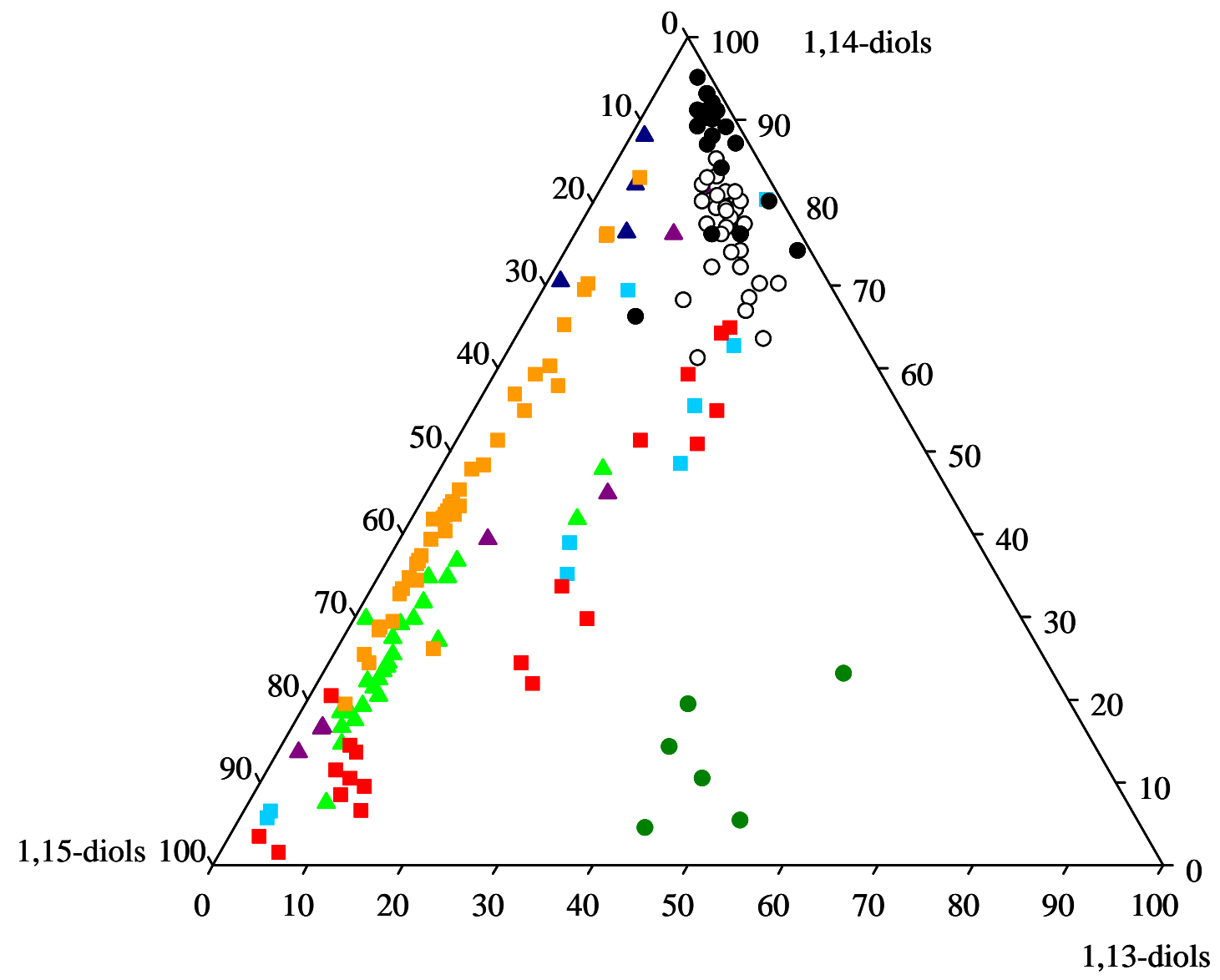

- Antarctic

- Arctic

- Estuarine

- Western South Atlantic

- Central South Atlantic

- West Africa

$\triangle$ Eastern South Atlantic

$\triangle$ Arabian Sea

$\triangle$ Others

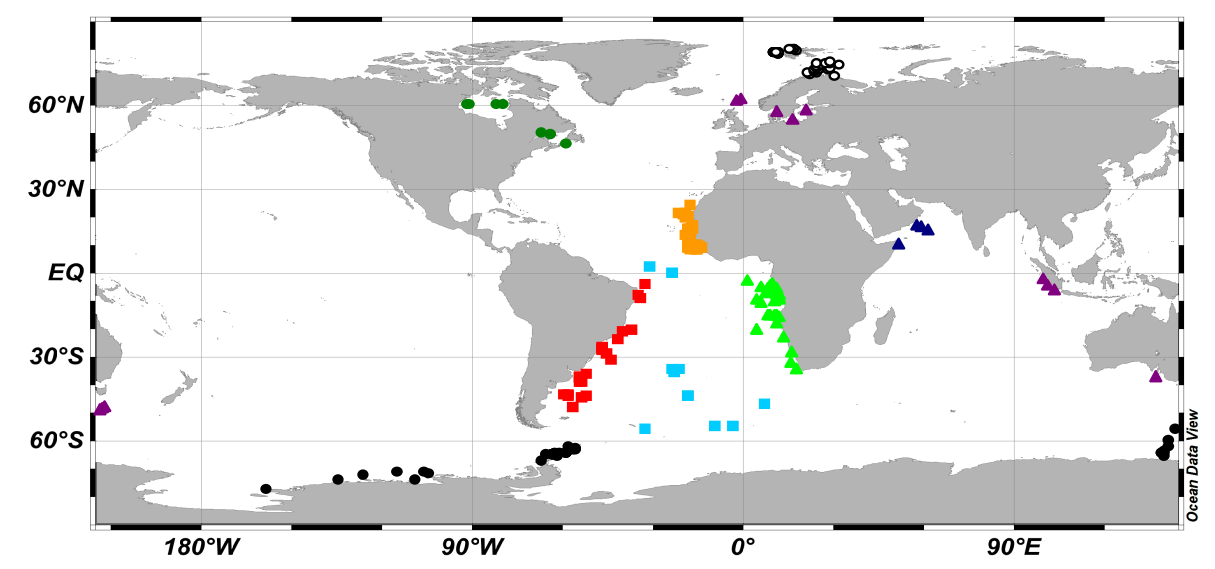


Fig. 3.

560
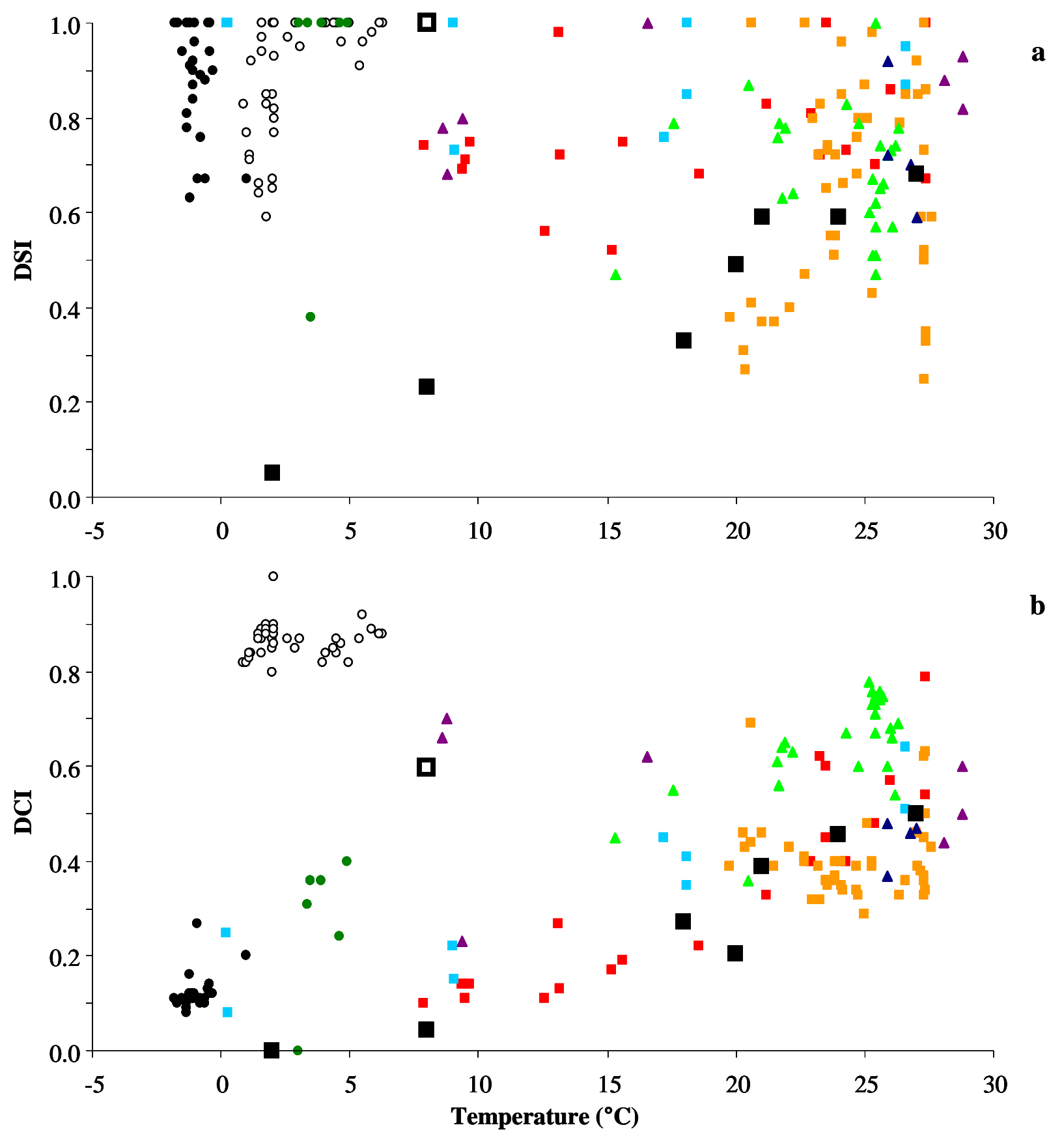

- Antarctic

- Arctic

- Estuarine
- Western South Atlantic $\triangle$ Eastern South Atlantic $\square$ Proboscia

- Central South Atlantic $\Delta$ Arabian Sea

- West Africa b 
Fig. 4.
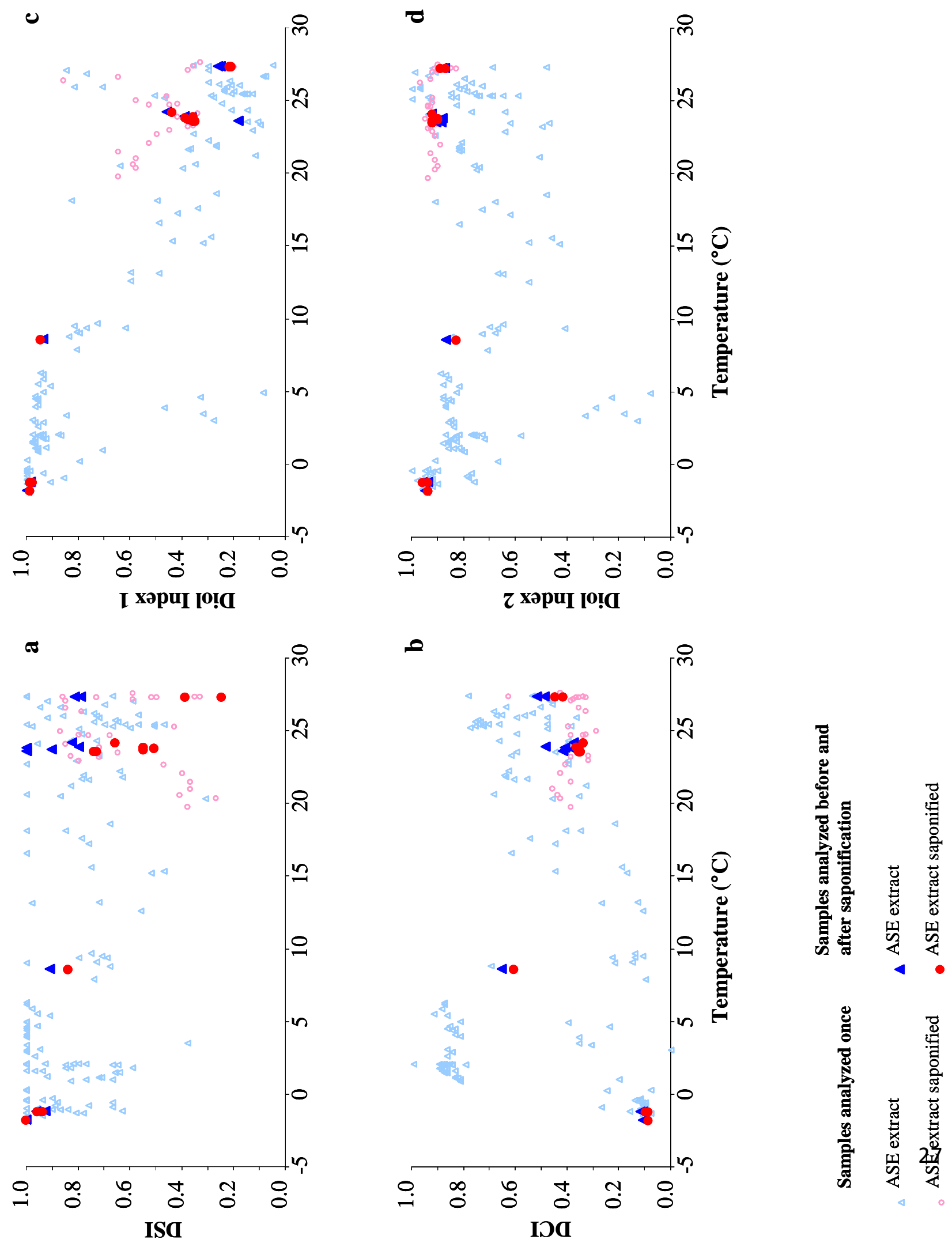
Fig. 5.

565
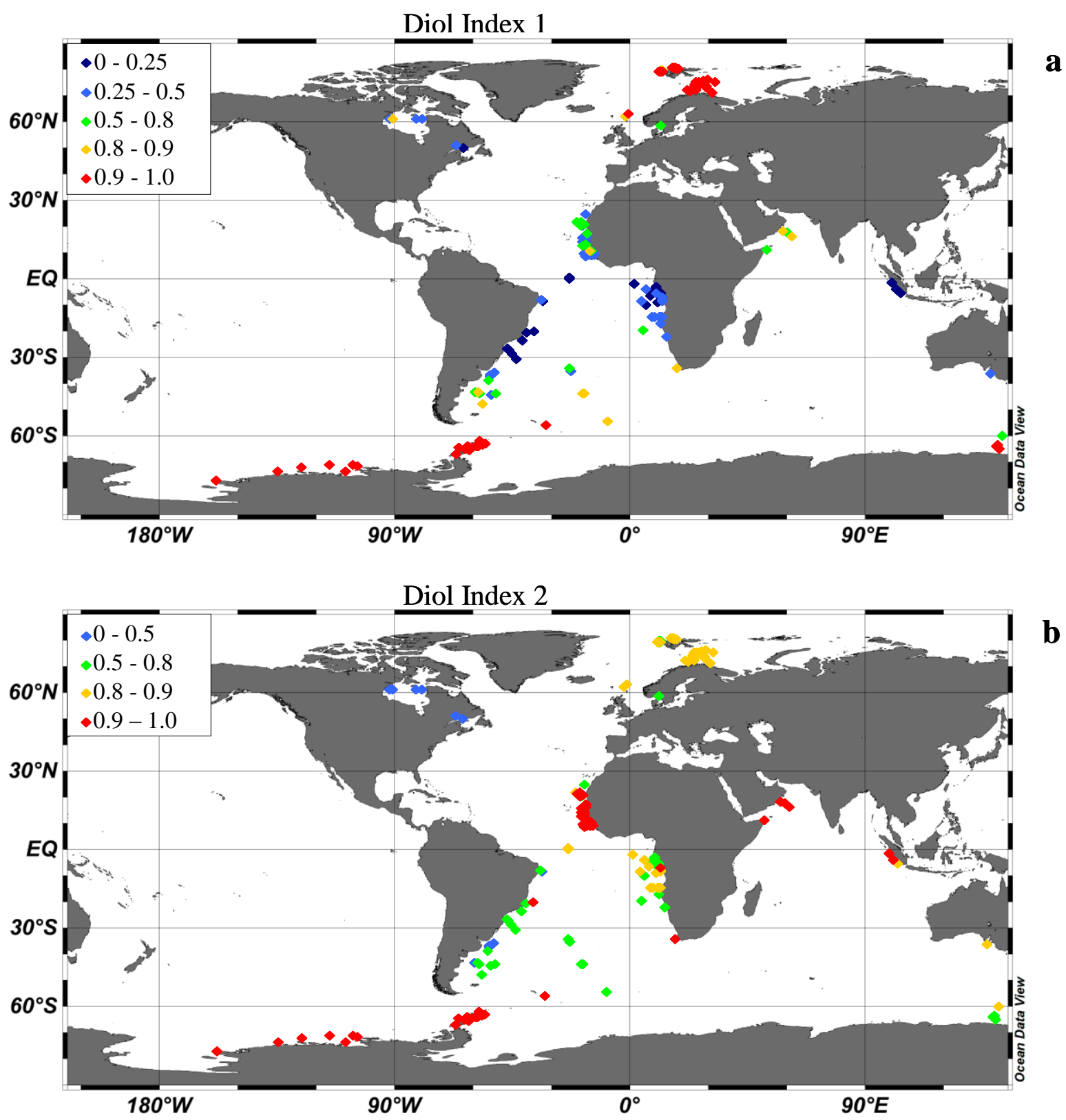
Fig. 6

570

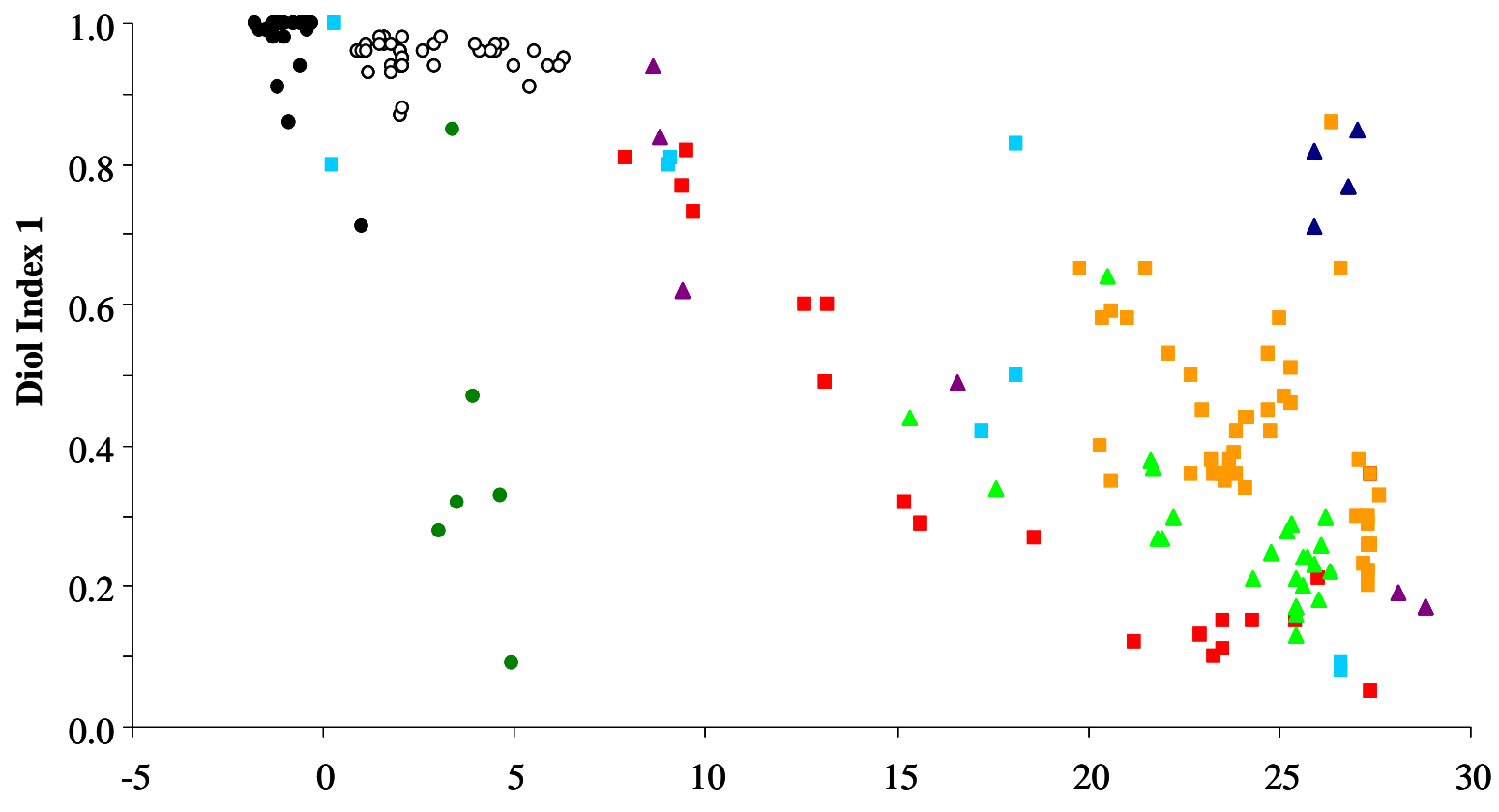

$\mathbf{a}$

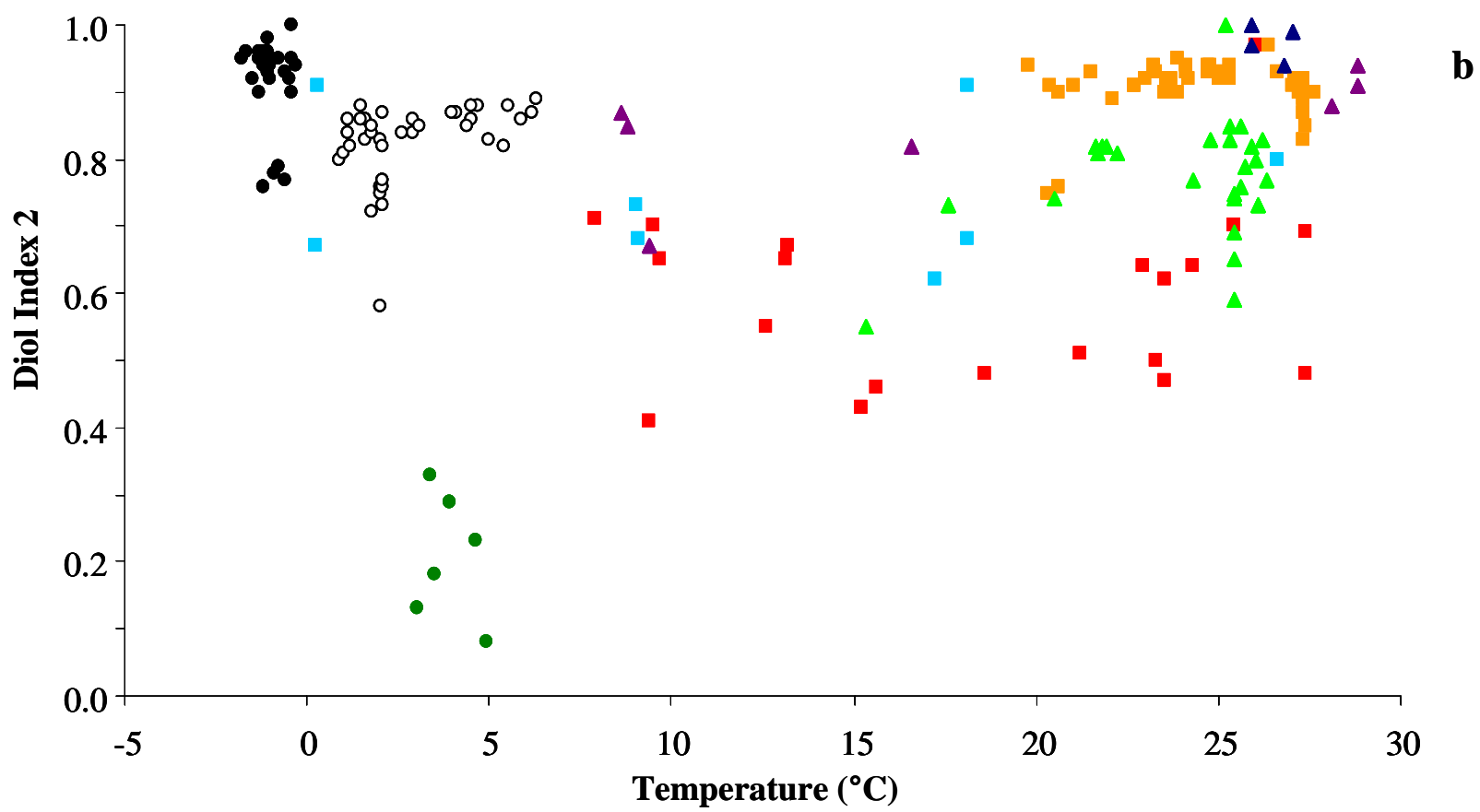

- Antarctic

- Western South Atlantic $\triangle$ Eastern South Atlantic

- Arctic

- Central South Atlantic $\triangle$ Arabian Sea

- Estuarine

$\square$ West Africa

$\triangle$ Others 